\title{
圧環試験によるセラミックフィルターの破壊挙動
}

\author{
伊藤義康・池田＼cjkstart誠・須山章子 \\ (株)東芝電力・産業システム技術開発センター, 230-0045 神奈川県横浜市鶴見区末広町 2-4
}

\section{Fracture Behavior of Ceramic Filter Using Diametral Ring Compression Test}

Yoshiyasu ITOH, Makoto IKEDA and Shoko SUYAMA

Power \& Industrial Systems Research \& Development Center, Toshiba Corp., 2-4, Suehiro-cho, Tsurumi-ku, Yokohama-shi 230-0045

\begin{abstract}
Fracture behavior of an O-ring specimen compressed by diametrically opposite external concentrated loads has been analyzed in terms of crack growth effect using a finite element method. The resulting advantages of the 0-ring compression test may enable to evaluate and distinguish between the fracture stress of internal and external surfaces of tubular cross sections. However, it is clarified by comparison with the C-ring compression test results that the fracture stress evaluation at the internal and external surfaces is difficult in a $\mathrm{SiC}$ ceramic filter. The difficulty arises from the occurrence of stable crack growth as confirmed by applying a compliance analysis. [Received June 3, 1999; Accepted August 13, 1999]
\end{abstract}

Key-words : Ceramic filter, Fracture strength, Weibull distribution, Rigidity, O-ring compression test, C-ring compression test, Compliance change, Crack growth, Finite element method

\section{1. 緒 言}

21世紀に向けて化石燃料枯渴の問題から，経済性に優れ安 定供給が可能なエネルギ一資源として石炭が見直され1)，これ を利用した発電システムの開発が行われている. 国内では地球 温暖化問題から二酸化炭素低減を達成すべく，加圧流動床燃焼 複合発電 (PFBC) と石炭ガス化複合発電 (IGCC) の高エネ ルギー効率発電技術の構築が進められている. いずれも蒸気 タービンとガスタービンを組み合わせたコンバインドサイクル 発電システムで，既に実用化段階に達している．しかし，ガス タービンに導入される石炭燃焼ガス中には高濃度の灰粒子や金 属蒸気が含まれており, タービンや熱交換器のエロージョン。 コロージョンに対する保護を，熱エネルギー損失を最小に抑え ながら行うためには, 高温状態での乾式除塵システムの開発が 重要課題である2).

当初の高温乾式除塵システムでは慣性分離や電気集塵などの 適用が検討されたが, 経済性の観点から現在では粗脱塵にサイ クロン（遠心分離方式の集塵装置）を用い，セラミックフィル ターを精密脱塵に用いる組み合わせが主流となっている.この 組み合わせ法は, 既に短期試験ではあるが，十分な性能を有す ることが確認されている3)。しかし，長期間の高い信頼性を有 するセラミックフィルターは，いまだ開発段階にあり，規格 化・標準化などはこれからの課題である. 現状ではセラミック フィルターに関する機能設計法, 強度設計法と, その基礎とな るデータベースの構築が強く望まれている. また, プラントで の実証試験においては，今後の実使用段階を迎えるにあたり， フィルターの耐久性評価が重要であることが示されている3),4).

一方，圧環試験とは円環試験片（O-リング試験片）を試験 機の圧縮治具間に置き，上下から加圧して破壊させ，その時の 荷重值から圧環強さを求める方法である. この方法は焼結含浸 軸受の圧環強さ測定方法として, JIS Z2507に規定されてい る. また，セラミックフィルターのようなセラミック部品では 円管形状が多いことから, 圧環試験は強度評価試験として使わ れており, 部品検査や品質検査などにも有効であるとされてい る5) 8). また, 円環の一部を切り欠いた試験片（C-リング試験 片）による压環試験も実施されている91010). しかしながら, セ ラミックフィルターに関する強度データは必ずしも十分に蓄積
されているとは言い難く，またセラミックフィルターの圧環試 験による破壊挙動についても十分には明らかにされていない.

以上より, 本研究では円管状の高温脱塵セラミックフィル ターを対象に強度データベースの蓄積を最終目標とし, そのた めの基礎的検討を行う.すなわち，セラミックフィルターの圧 環試験法に注目し，O-リング試験片の破壊挙動に関して解析 的検討を加える. むた, 実際に $\mathrm{SiC}$ 系のセラミックフィル ターを用いて O-リング, C-リング試験片の圧環試験を行い, 実験的に破壊挙動を明らかにする.

\section{2. 解析方法とモデル}

現在, 実用化が進められている高温脱塵セラミックフィル ターは, その形状から片端閉じ円管状のキャンドル型と, 両端 開放円管状のチューブ型と呼ばれている 2 種類が主流となっ ている ${ }^{4)}$. 図 1 に示す O-リング形状の 2 次元平面モデルは, このような実際のセラミックフィルターを輪切りにして得られ る円環試験片であり, 内径 $R_{1} \quad(=20 \mathrm{~mm})$, 外形 $R_{2} \quad(=30$ $\mathrm{mm})$, 板厚 $h(=10 \mathrm{~mm})$ とした.

解析には汎用の有限要素法プログラム（四角形平面ひずみ要 素）を用い，対称性から図中に示す斜線部分を要素分割し，応 力解析を行った. 解析は, (a) 円環試験片の上下端に集中荷重 を負荷した場合, その後に(b)内径 A 点に荷重軸に沿ってき裂 が進展した場合, (c)A 点のき裂が進展し O-リングが 2 分され た場合, その後に(d)外径 B 点に荷重軸に垂直方向にき裂が進

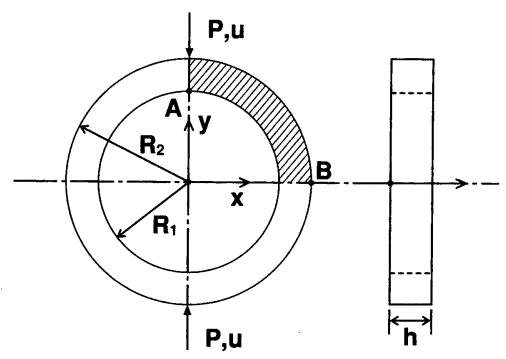

Fig. 1. Analysis model for O-ring diametral compression specimen. 


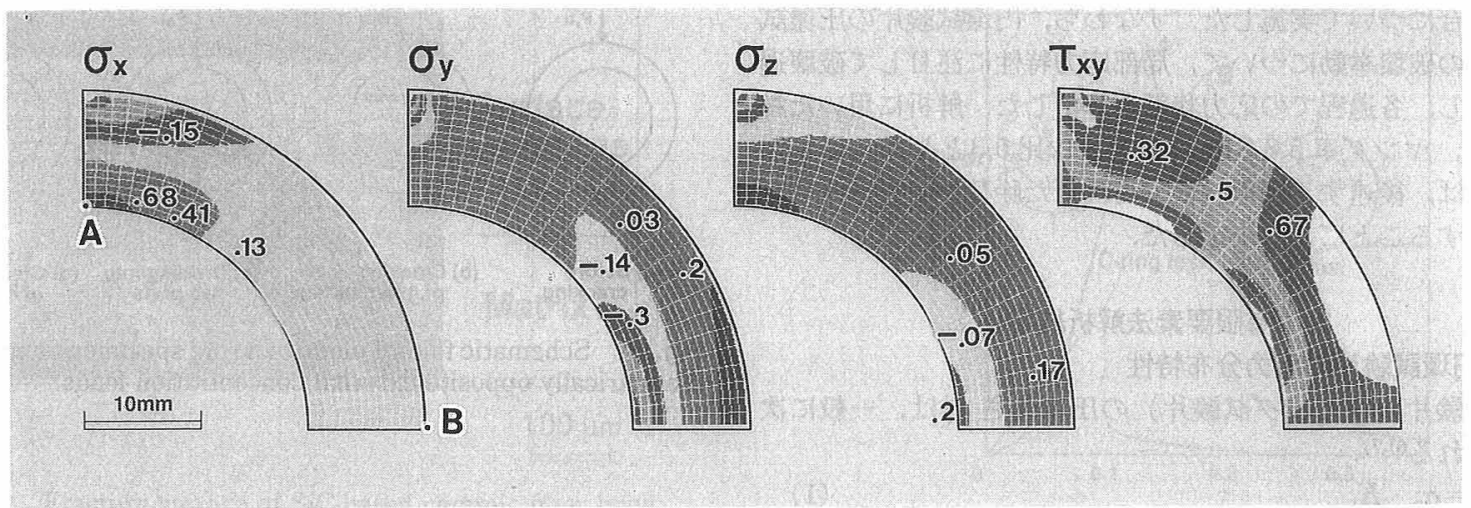

(a)

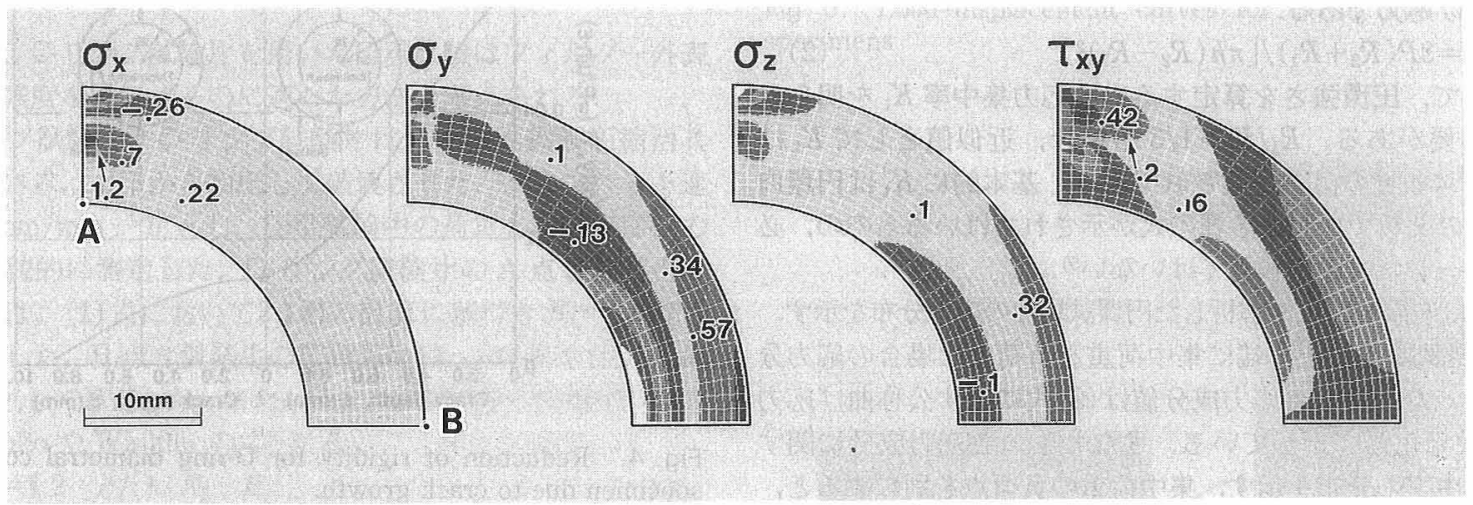

(b)

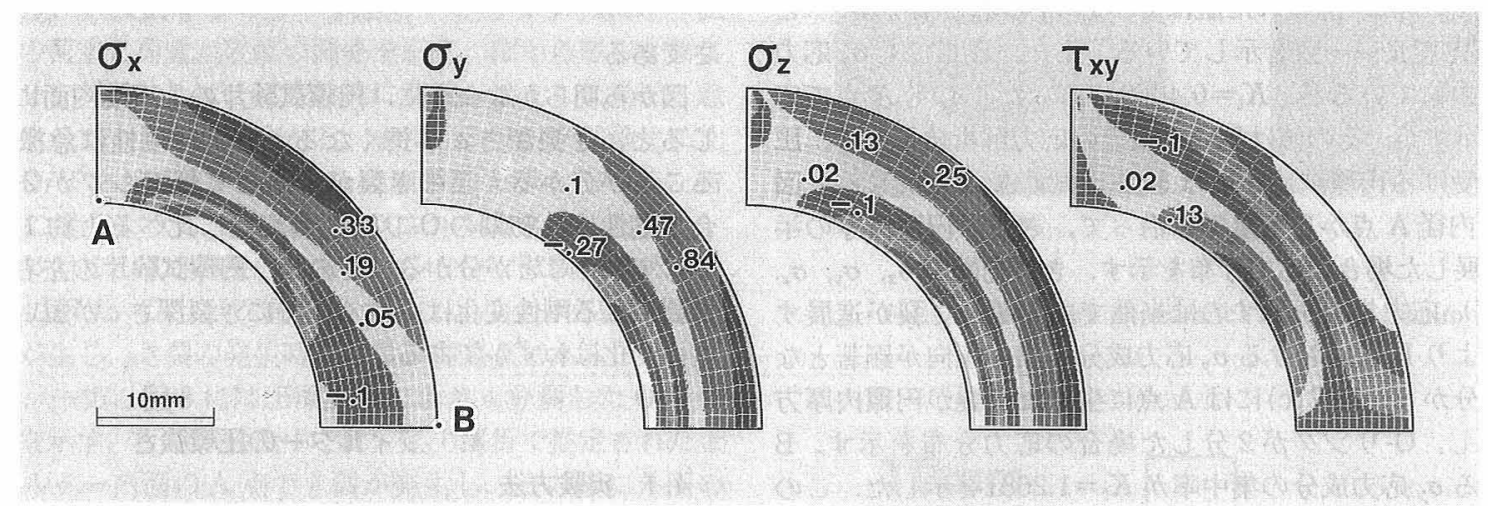

(c)

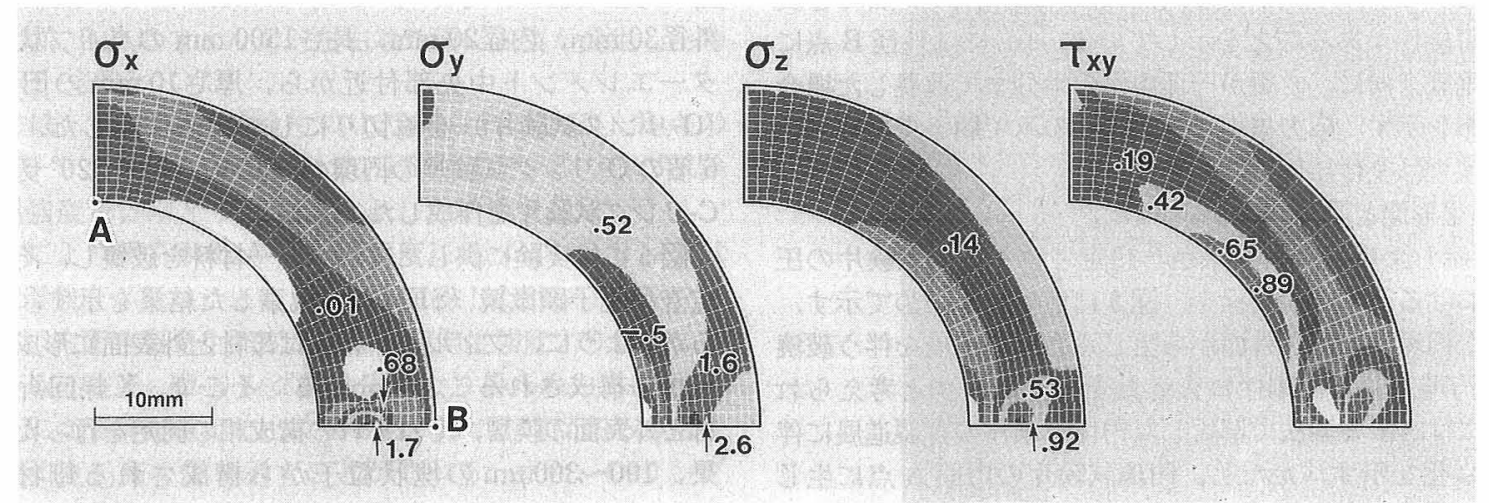

(d)

Fig. 2. Stress distribution obtained by finite element analysis.

(a) O-ring before cracking.

(b) Cracking at top and bottom of inner surface.

(c) Dividing into two parts.

(d) Cracking at right and left of outer surface. 
展した場合について実施した。すなわち, 円環試験片の圧環試 験過程での破壞挙動について, 局部応力特性に注目して破壊過 程を推測し, 各過程での応力状態を解析した. 解析に用いた材 料定数は, ヤング率 $5.8 \mathrm{GPa}$, ポアソン比 0.3 とした. 用いた ヤング率は, 後述する圧環試験で得られた除荷コンプライアン スを計測することにより決定した。

\section{3. 有限要素法解析結果}

\section{1 円環試験片の応力分布特性}

円環試験片（O-リング試験片）の王環強さ $\sigma_{\mathrm{f}}$ は, 一般に次 式で表される6),7).

$$
\sigma_{\mathrm{f}}=\sigma_{\mathrm{n}} \cdot K_{\mathrm{t}}
$$

ただし， $K_{\mathrm{t}}$ は図 1 の A 点の応力集中率で， $\sigma_{\mathrm{n}}$ は次式で示され る公称曲げ応力である.

$$
\sigma_{\mathrm{n}}=3 P\left(R_{2}+R_{1}\right) /\left[\pi h\left(R_{2}-R_{1}\right)^{2}\right]
$$

したがって，圧環強さを算定するには応力集中率 $K_{\mathrm{t}}$ を明らか にする必要がある. $R_{1} / R_{2}>1 / 3$ の場合, 近似值として $K_{\mathrm{t}}$ は 1.0 や 0.954 などの值が提案されている. 基本的に $K_{\mathrm{t}}$ は円環肉 厚々外径の関数であり, 各種の式が示されてはいるものの, 必 ずしも統一した式が使われてはいない5).

図 2 には有限要素法で解析した円環試験片の応力分布を示す. （a）は円環試験片の上下端に集中荷重を負荷した場合の応力分 布である.ただし，各応力成分值は(2)式に示す公称曲げ応力 $\sigma_{\mathrm{n}}$ で無次元化して示している．すなわち，各応力成分に関す る応力集中率の分布を示す. 集中荷重の負荷点を別にすると, 図中 $\mathrm{A}$ 点で $\sigma_{x}$ 応力成分が最も高い集中率を示しており， $K_{\mathrm{t}}$ $=1.051$ であった. 得られた值は Peterson の応力集中率6),7) と $0.3 \%$ 誤差で良い一致を示している. また， B 点でも $\sigma_{y}$ 応力 成分が集中しているが， $K_{\mathrm{t}}=0.4069 て ゙ め っ た ， \sigma_{z}$ \& $\mathrm{A}$ 点で応 力集中を示すが，その值は低い，以上の応力解析結果から，圧 縮負荷を受ける円環試験片ではき裂はまず A 点で生じる．図 2(b)には内径 $\mathrm{A}$ 点から荷重軸に沿って, き裂が円環肉厚の半 分まで進展した場合の応力分布を示す。き裂先端で $\sigma_{x}, \sigma_{y}, \sigma_{z}$, $\tau_{x y}$ 共に高い応力集中を示すのは当然であるが，き裂が進展す ることにより $\mathrm{B}$ 点における $\sigma_{y}$ 応力成分の集中傾向が顕著とな ることが分かる．図 $2(\mathrm{c})$ には $\mathrm{A}$ 点に生じたき裂が円環肉厚方 向に貫通し，O-リングが 2 分した場合の応力分布を示す. B 点における $\sigma_{y}$ 応力成分の集中率が $K_{\mathrm{t}}=1.2681$ を示した．この ように $\mathrm{A}$ 点でき裂が生じることにより $\mathrm{B}$ 点の $\sigma_{y}$ 応力值が高く なることは， A 点で生じたき裂が貫通する以前に B 点でき裂 が生じる可能性があることを示している。（d）には外径 B 点に 荷重軸に垂直方向に，き裂が円環肉厚の半分まで進展した場合 の応力分布を示す. 応力集中はき裂先端のみで顕著であり，そ の他の領域では全体に低い值を示す.

\section{2 破壊形態と剛性変化}

3.1節で示した応力解析結果から想定される円環試験片の圧 環試験における基本破壊過程を, 図 3 に簡単にまとめて示す. このような円環の内面と外面から生じるき裂の進展を伴う破壊 挙動は, 円環試験片の剛性に大きな变化を及ほすと考えられ る. 図 4 には有限要素法で解析した円環試験片のき裂進展に伴 う剛性の変化を示す.ただし, 円環試験片の内面 A 点に生じ たき裂が円環肉厚方向に貫通した後に, 外面 B 点にき裂が進 展する場合の解析結果である. 円環試験片の剛性 $R$ は, 集中 荷重 $P(\mathrm{~N})$ を加えたときに生じる荷重点変位 $u(\mathrm{~mm})$ から， 次式により計算した。

$$
R=P /(u \cdot h \cdot E)
$$

ただし， $E\left(\mathrm{~N} / \mathrm{mm}^{2}\right)$ はヤング率で, $h(\mathrm{~mm})$ は円環試験片厚

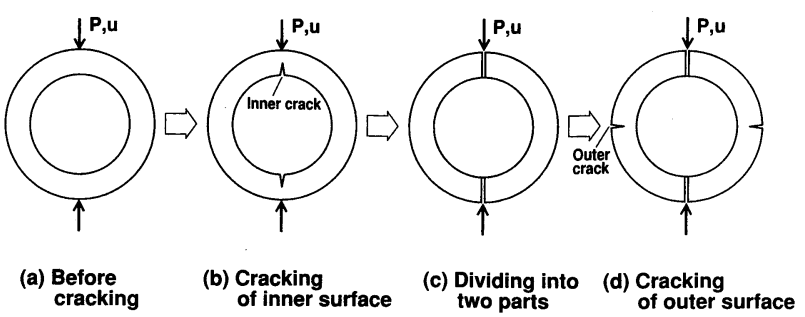

Fig. 3. Schematic failure mode of a ring specimen compressed by diametrically opposite external concentration loads.

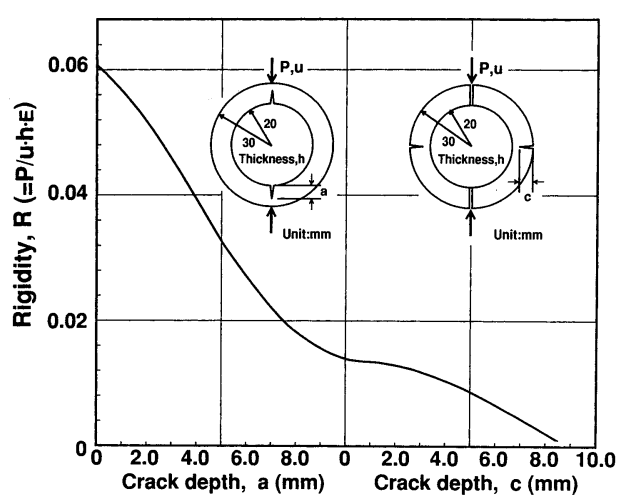

Fig. 4. Reduction of rigidity for O-ring diametral compression specimen due to crack growth.

\section{さである.}

図から明らかなように，円環試験片の上下端内面にき裂が生 じると, き裂深さ $a$ が長くなるとともに剛性は急激に低下す ることが分かる．このき裂が貫通して O-リングが 2 分した場 合の剛性は, 初期の O-リングの剛性に比べると約 $1 / 4$ まで低 下していることが分かる．その後, 円環試験片の左右端外面の き裂による剛性変化は少なく，特にき裂深さ $c$ が短い範囲では 剛性変化はわずかである.

\section{4. フィルターの圧環強さ}

\section{1 実験方法}

実験に供したフィルター材料は, Schumacher 製の高温ガス 用フィルターエレメント (DIA-Schumalith TF20) である. 外径 $30 \mathrm{~mm}$, 内径 $20 \mathrm{~mm}$, 長さ $1500 \mathrm{~mm}$ のパイプ状のフィル ターエレメント中央部付近から, 厚さ $10 \mathrm{~mm}$ の円環試験片 (O-リング試験片) を輪切りにして18個採取した. そのうち 6 個の O-リング試験片の円環の一部を, 角度で $20^{\circ}$ 切り欠いて C-リング試験片を作成した.

図 5 には実験に供したフィルター材料を破壊し，その破面を 走查型電子顕微鏡（SEM）で観察した結果を示す．図から明 らかなように, フィルター材料は母材と外表面に形成された膜 層から構成されることが分かる. そこで，X線回折により母 材と外表面の膜層, それぞれの構成相の同定を行った．その結 果, $100 \sim 300 \mu \mathrm{m}$ の塊状粒子から構成される母材は $\beta$-SiC, $\mathrm{SiO}_{2}$ (クリストバライト), $\mathrm{Al}_{2} \mathrm{O}_{3}$, 外表面膜層は $\mathrm{SiC}$ と微量 の $\mathrm{SiO}_{2}, \mathrm{Al}_{2} \mathrm{O}_{3}$ 短繊維からなることを確認した.このように圧 環試験に供したフィルター材料は, 母材と外表面膜層が異なる 材質であることから, そのき裂発生強度もフィルターの内外表 面で異なる可能性があると考えられる.このような観点から， O-リング試験片を用いた圧環試験は基本的にはフィルター母 


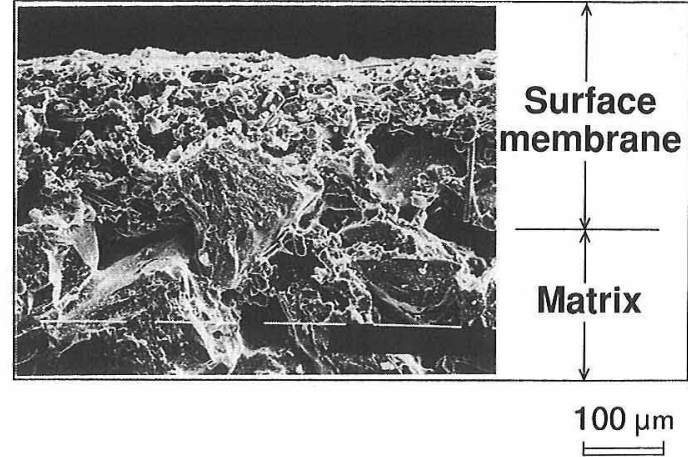

Fig. 5. Fracture surface of SiC-based ceramic filter body.

材の強度，C-リング試験片を用いた圧環試験はフィルター外表 面膜層の強度を評価するのに適した方法と考えられる。

O-リング試験片, C-リング試験片はいずれも鋼製圧縮治具 の間にはさみ, 上下から加圧して破壞させた. クロスヘッド速 度は $0.5 \mathrm{~mm} / \mathrm{min}$ 一定とし, 压環試験中の荷重と荷重点変位の 関係を連続的に測定した。 Oーリング試験片のA点き裂発生の 圧環強度は，(1)式において3.1節の計算に基づき $K_{\mathrm{t}}=1.051$ と して算定した，B 点き裂発生の圧環強度は，(1)式に打いて $K_{t}$ =1.2681として算定した. また，C-リング試験片の圧環強度は, Timoshenko やWinklerの式)に基づいて次式で算定した.

$$
\sigma_{\mathrm{f}}=1.2 \cdot P /\left[h\left(R_{2}-R_{1}\right)\right]
$$

\section{2 実験結果}

図 6 には, 代表的な O-リング試験片，C-リング試験片の压 環試験中の荷重と荷重点変位の関係を示す. 図から明らかなよ うに，C-リング試験片はほぼ直線的に荷重が増大した後に，急 速破壞が生じている様子が分かる．また，C-リング試験片に比 ベると，O-リング試験片は複雑な破壊挙動を示している。特 に，図中に示すように A 点, B 点の二つの山を示した後に, 急速破壞が生じる点が特徵的である.C-リング試験片の破壊形 態を図 7 K示す.C-リング試験片ではフィルター外面の $\mathrm{B}$ 点 からき裂が生じ，き裂の発生時期が最高荷重点であることが観 察された。一方, 図 8 には圧環試験により 4 分裂したO-リン グ試験片を示す. 圧環試験途中では, 応力解析で推定されたよ うにフィルター内面の A 点でき裂が発生し, その後に外面の $\mathrm{B}$ 点で生じる様子が観察された。すなわち, 図 6 の荷重と荷 重点変位曲線に示す $\mathrm{A}$ 点はフィルター上下端内面にき裂が発 生した時期, B 点はフィルター左右端外面にき裂が発生した時 期と,ほぼ一致していた。

図 9 には, O-リング試験片により得られた A 点, B 点の 二つのピークより求められた二つの王環強度と, C-リング試験 片の圧環強度を, ワイブルプロットした結果を示す．－リン グ試験片により得られた $\mathrm{A}$ 点圧環強度に比べて，C-リング試 験片の圧環強度が低いことから, 実験に供したセラミックフィ ルターは, 内面き裂発生強度が外面き裂発生強度よりも高いこ とが分かる. なた，O-リング試験片により得られた A 点圧環 強度と, B 点王環強度とを比較すると, わずかではあるが常に $\mathrm{A}$ 点圧環強度が高い值を示すことが分かる，また，Oーリング 試験片により得られた B 点圧環強度が, フィルター左右端外 面にき裂が発生した時期の強度とすると，C-リング試験片の圧 環強度と一致すると考えられる，しかしながら，図 9 からは 試験片数が少ないものの, C-リング試験片の圧環強度は明らか に低めの值を示す．これは O-リング試験片での B 点圧環強度 算定において ○-リングが完全に 2 分したと仮定しているが，

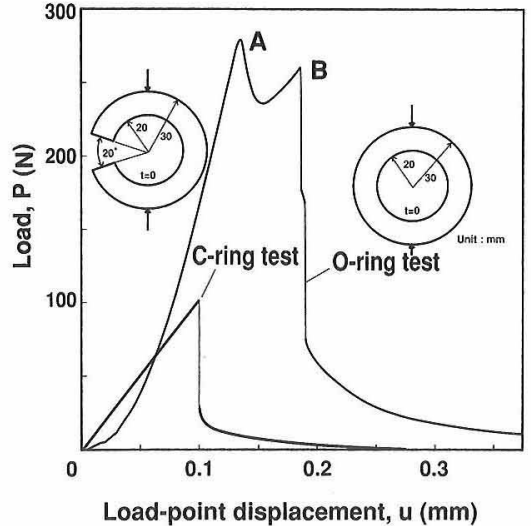

Fig. 6. Load-displacement curves for O-ring and C-ring test specimens.

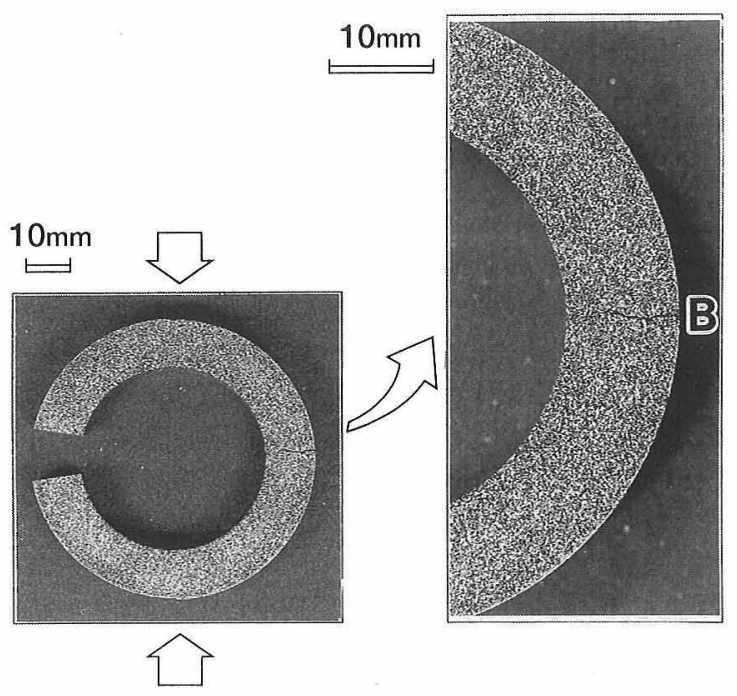

Fig. 7. Fracture appearance of C-ring specimen.

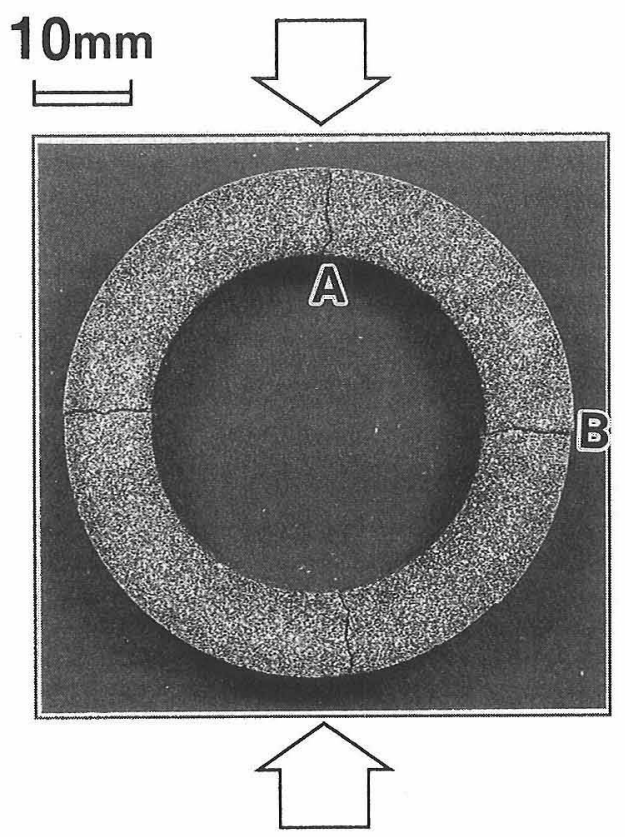

Fig. 8. Fracture appearance of O-ring specimen. 


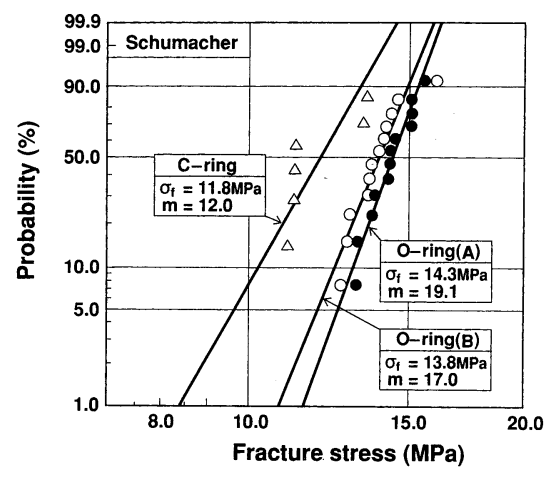

Fig. 9

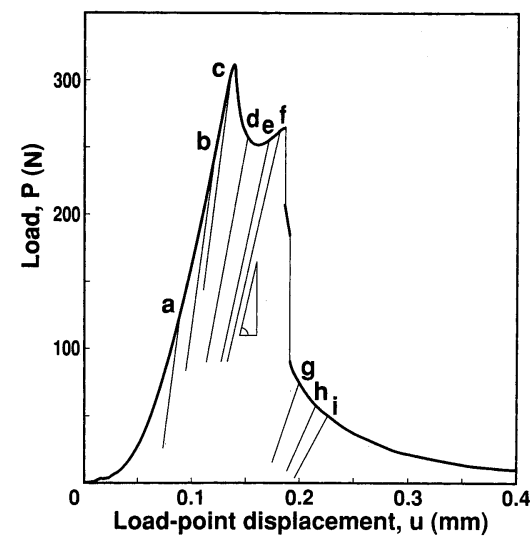

Fig. 10

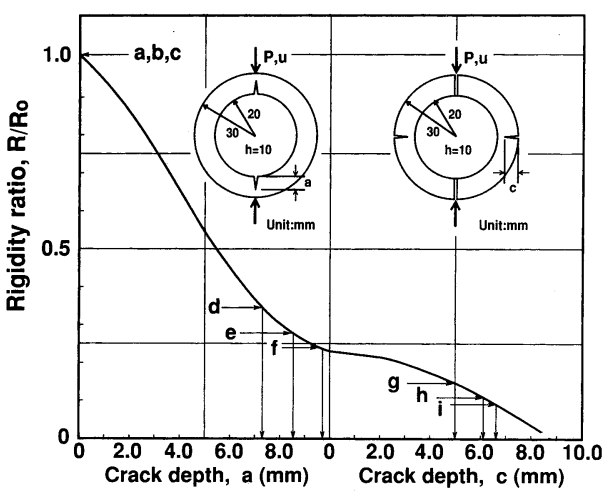

Fig. 11

Fig. 9. Weibull distribution of fracture stress of ring specimens compressed by diametrically opposite external concentration loads. Fig. 10. Compliance test results at various displacement levels.

Fig. 11. Crack depth estimation from compliance change.

実際には $\mathrm{A}$ 点でのき裂が貫通しておらず， B 点での応力集中 が緩和されているためと考えられる.

\section{5. き裂進展挙動評価に関する考察}

前章まで, 円環試験片のき裂進展特性については解析的検討 に基づいて検討を進めてきたが, 以下では除荷コンプライアン ス法によるき裂進展特性の評価を行う. 図10には, 複数の0リング試験片を用いて $\mathrm{a} \sim \mathrm{i}$ の各変位レベルで除荷し, 得られ た荷重と荷重点変位関係を示す. 図から a c c の変位レベルで は, 荷重-荷重点変位関係の勾配, すなわち除荷コンプライア ンスにほとんど変化は見られない。これは円環試験片に, まだ き裂が生じていないためで, 剛性が変化していない.この荷重荷重点変位関係の勾配を用いれば, 図 4 の有限要素法解析結 果からフィルターのヤング率を計算することができる. 得られ た值は $5.8 \mathrm{GPa}$ であった. $\mathrm{d} \sim \mathrm{f}$ の変位レベルでは, 徐々に荷 重-荷重点変位関係の勾配が緩やかになる傾向を示す． $\mathrm{g} \sim \mathrm{i}$ の 変位レベルに至ると, 荷重-荷重点変位関係の勾配は低下して いることが分かる. 図 4 に示した円環試験片のき裂進展に伴 う岡性変化の解析結果を用いると, $\mathrm{d} \sim \mathrm{i}$ の各変位レベルにお けるき裂進展挙動を近似的に評価することができる. 図11は図 4 の縦軸を, き裂が生じていない円環試験片の剛性 $R_{0}$ で無次 元化したものである. 図中には, d〜i の各変位レベルにおけ る荷重一荷重点変位関係の勾配の变化率を書き込んである.た だし, 円環試験片の内面 $\mathrm{A}$ 点に生じたき裂が貫通した後に, 外面 B 点にき裂が進展すると仮定した場合の結果である. 図 から明らかなように, フィルター上下端内面の $\mathrm{A}$ 点にき裂が 生じ荷重低下を示す $\mathrm{c} \sim \mathrm{d}$ の間で，き裂は相当に深く進展する ことが分かる．すなわち， d の変位レベルでは，き裂深さ $a$ は フィルター厚さの70\%程度となっている．また， $\mathrm{f} \sim \mathrm{g}$ の荷重 低下の間でき裂深さ $c$ もフィルター厚さの $50 \%$ 程度と深く進展 する.

以上の結果からも, 図 6 に示す円環試験片の荷重-荷重点変 位関係に見られるピークは, 円環試験片の内面 $\mathrm{A}$ 点と $\mathrm{B}$ 点に き裂が生じた時点と一致すると考えられる. また, いずれもピー ク後の荷重低下の間にフィルター厚さ方向に深くき裂が進展す るが，実験の範囲内では貫通には至っていないと考えられる.

\section{6. 結 論}

（1）内径 $20 \mathrm{~mm}$, 外形 $30 \mathrm{~mm}$, 板厚 $10 \mathrm{~mm}$ の円環試験片 の上下端に集中荷重を負荷した場合，上下端内面で $\sigma_{x}$ 応力集 中係数 $K_{\mathrm{t}}=1.051$ であった. 上下端内面のき裂が進展すると共 に, 左右端外面の $\sigma_{y}$ 応力集中係数は, $K_{\mathrm{t}}=0.4069$ から 1.2681 に上昇した。

（2） 円環試験片の上下端内面にき裂が生じると，き裂が長 くなるとともに剛性は急激に低下した，き裂が貫通して円環が 2 分した場合の剛性は, 初期剛性に比べ約 $1 / 4$ まで低下した. 円環試験片の左右端外面のき裂による剛性变化は少なく，き裂 が短い範囲ではわずかである.

（3） SiC 系フィルター材料の圧環試験に抢いて，荷重一荷重 点変位曲線には二つのピークが認められ, その後に急速破壊し た. 最初のピークはフィルター上下端内面にき裂が発生した時 点, 次のピークはフィルター左右端外面にき裂が発生した時点 とに対応している.

（4）実験に供した SiC 系フィルターは，母材と外表面の組 成が異なり O-リング試験片により得られた内面き裂発生強度 に比べて，C-リング試験片による外面き裂発生強度が低い。

\section{文 献}

1) Y. Itoh, Sciene of Machine, 44, 1136-42 (1992) [in Japanese].

2) T. Kanaoka, J. Energy Soc. Japan, 77, 170-76 (1998) [in Japanese].

3) S. Itoh and T. Yamaguchi, J. Energy Soc. Japan, 77, 193-99 (1998) [in Japanese].

4) NEDO IEA-FBC Int. Committee, "FBC in Japan" (1997) pp. 384-458 [in Japanese].

5) Ceramics Editrial Committee ed., "Mechanical Properties of Ceramics," Ceram. Soc. Japan (1979) pp. 65-66 [in Japanese].

6) R. E. Peterson, "Stress Concentration Design Factors," John Wiley \& Sons, New York (1953) p. 101.

7) W. D. Pilkey, "Peterson's Stress Concentration Factors 2nd ed.," John Wiley \& Sons (1997) p. 437.

8) E. A. Ripperger and N. Davids, Trans. Am. Soc. of Civ. Eng., Founded Nov. 5, 1852, Transactions, Paper No. 2308 (1852) pp. 619-35.

9) J. R. G. Evans and R. Stevens, Br. Ceram. Trans. J., 83, 1418 (1984).

10) M. K. Ferber, V. J. Tennery, S. B. Waters and J. Ogle, J. Mater. Sci., 21, 2628-32 (1986). 